
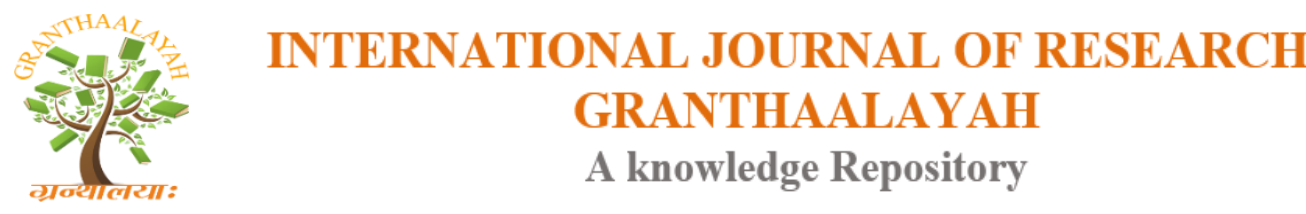

Science

\title{
RAINFALL TREND ANALYSIS OF A MINI WATERSHED: A CASE STUDY ON DEGRADING LAKES/TANKS
}

\author{
Pradeep Raja K.P. *1, Suresh Ramaswwamy Reddy ${ }^{2}$ \\ ${ }^{* 1}$ Research Scholar, Department of Civil Engineering, BMS College of Engineering, \\ Basavanagudi, Bengaluru, Karnataka, India -560019 \\ ${ }^{2}$ Professor, Department of Civil Engineering, BMS College of Engineering, Basavanagudi, \\ Bengaluru, Karnataka, India -560019
}

\begin{abstract}
India as a tropical country, depends solely on south west Monsoon. Southwest monsoon spans between June and September. The present study is aimed to carry out the probable trend of rainfall and to evaluate its implications on the tanks in Hunsur taluk of Mysore district, Karnataka, India. These tanks were the livelihood sources of water for the farmers in the command area. The lakes considered under this case study have been completely dried up in the recent past. Inconsistency of rainfall is one of the factors which govern the degradation of Lakes. Trend analysis is carried on 40 years daily rainfall data (1975-2014) for monthly, seasonal and annual average values using Mann-Kendall test and Sen's slope estimation. The analysis shows 'no trend' for the months of January, February, March and June. There is an 'increasing trend' for the months of August, October and December. However, there is a 'decreasing trend' for the months of April, May, July, September and November. The decadal variation indicates a very significant decrease of rainfall for the months of June and July; particularly in the recent decade (2005-2014) and hence a 'negative trend' in the South-West monsoon. This may be one of the reasons for the deterioration of tanks in the study area.
\end{abstract}

Keywords: Mann-Kendall Test; Sen's Slope Estimator; Bilikere and Halebidu; Trend Analysis; Minor Irrigation Tanks.

Cite This Article: Pradeep Raja K.P., and Suresh Ramaswwamy Reddy. (2018). "RAINFALL TREND ANALYSIS OF A MINI WATERSHED: A CASE STUDY ON DEGRADING LAKES/TANKS." International Journal of Research - Granthaalayah, 6(7), 28-44. https://doi.org/10.29121/granthaalayah.v6.i7.2018.1281.

\section{Introduction}

Hunsur is a town and a taluk headquarter in Mysore district of southern India. It is situated on the western side of Mysore. The suburb is described by denudational uplands; the general elevation in the region varies from $700 \mathrm{~m}$ to $800 \mathrm{~m}$ above mean sea level (MSL) except for the hills and ridges. $90 \%$ of the population in the region depends on agriculture and horticulture for their livelihood. 
Rainfall is an essential component of the climate, and transition in their pattern can influence the local environment, flora and fauna, water availability in tanks/lakes, agricultural production, irrigational practices and crop management. Various studies have been undertaken to evaluate the effect of climatic changes on water resources, farming and crop production at a global, regional and local levels. There are seven (7) minor irrigation (MI) tanks in the taluk of Hunsur. Among these seven tanks, two tanks under study have dried up completely since 2004 . The south west monsoon in this region is around $50 \%$ and that of north east monsoon is around $30 \%$. The clustering of rainfall during monsoon months affects water scarcity in the non-monsoon months.

Fluctuations in precipitation trend have been studied extensively by several investigators across the country and the world. A research report published by CSIR; (Ramesh and P 2007) shows that the Indian summer monsoon is shrinking in its duration as well as in spatial coverage. Analysis of long term rainfall (Kumar et al. 2010), 135 years (1871-2005) revealed 'no trend' for December, January and February, 'negative trend' for March, April, May, June and July and 'positive trend' for August, September and October; for south-interior Karnataka in which this study area is a part. Studies conducted from 1902-1980 (Jain and Kumar 2012), for Cauvery basin, shows an 'increasing trend' for annual rainfall, 'decreasing trend' for pre-monsoon, insignificant 'positive trend' for monsoon and very significant 'increasing trend' for post-monsoon using Sen's slope estimator. Investigation of 100 year data (1901-2002) over Cauvery basin (Sushant et al. 2015) using MK test shows decreasing trend for winter season, increasing trend in the post-monsoon for the catchment in Mysore district. Modified MK test (Hamed and Ramachandra Rao 1998) has been used for auto correlated data and noticed that the accuracy of the MK-modified test in terms of its empirical significance level was found to be superior to that of the original MK trend test without any loss of power. Excel Template application MAKESENS (Salmi et al. 2002) is used for finding trends of various atmospheric pollutants and reported that, in the MK test missing values are allowed and the data need not conform to any particular distribution. The Sen's method is not greatly affected by gross data errors or outliers and also it can be computed when data are missing.

An understanding of trends and the magnitude of variations due to climatic changes at the basin scale would provide useful information for the planning, development and management of water resources (Singh et al. 2008). Some of the studies in India, related to the variability of rainfall using Mann-Kendall and Sen's slope estimator are carried by several instigators and researchers (Ganguly et al. 2015), (Jagadeesh and Anupama 2014), (Nikhil Raj and Azeez 2012). Some of the investigations outside India are carried in Bangladesh (Rahman and Begum 2013), in Serbia (Gavrilov 2016), in Tasmania, Australia (Laz and Rahman 2014).

The objective of this analysis is to find the 'trend' of rainfall, to correlate the results with the morphological investigation, to find the surface runoff characteristics and to establish the methods to be adopted in restoring and rejuvenating the degrading lakes/tanks.

\section{Study Area}

The fluctuation of annual, seasonal and monthly rainfall data was analyzed for the Hunsur taluk of Mysore district. The study area (Figure.1) under consideration is a very small agricultural watershed which has two major irrigation tanks; Bilikere and Halebeedu. The Bilikere tank can store up to a capacity of $21 \mathrm{MCft}$, whereas Halebeedu can store upto $18 \mathrm{MCft}$ of water (source; 
PWD- Govt. of Karnataka). Both the lakes are rain fed perennial waterbodies. The basin is enclosed between 76 31'4"-E \& 76 25'46"-E longitude and $12^{\circ} 22^{\prime} 00^{\prime \prime}-\mathrm{N} \& 12^{\circ} 17^{\prime} 38^{\prime \prime}$-N latitude having a total geographical area of $44.85 \mathrm{Km}^{2}$. The watershed is a part of Lakshman theertha river basin which is a tributary to Cauvery River. The catchment of both the tanks are predominantly covered with agricultural and farm land. The tanks get flooded during monsoon rains, thereby being subjected to dryness when the monsoon fails.

Observation of satellite images right from 1976 till 2014 reveals that both the lakes were full in most of the years till 2004 except in 1990 and 1998 where the annual rainfall is considerable deficient. Some of the satellite images are shown in Figure 2.

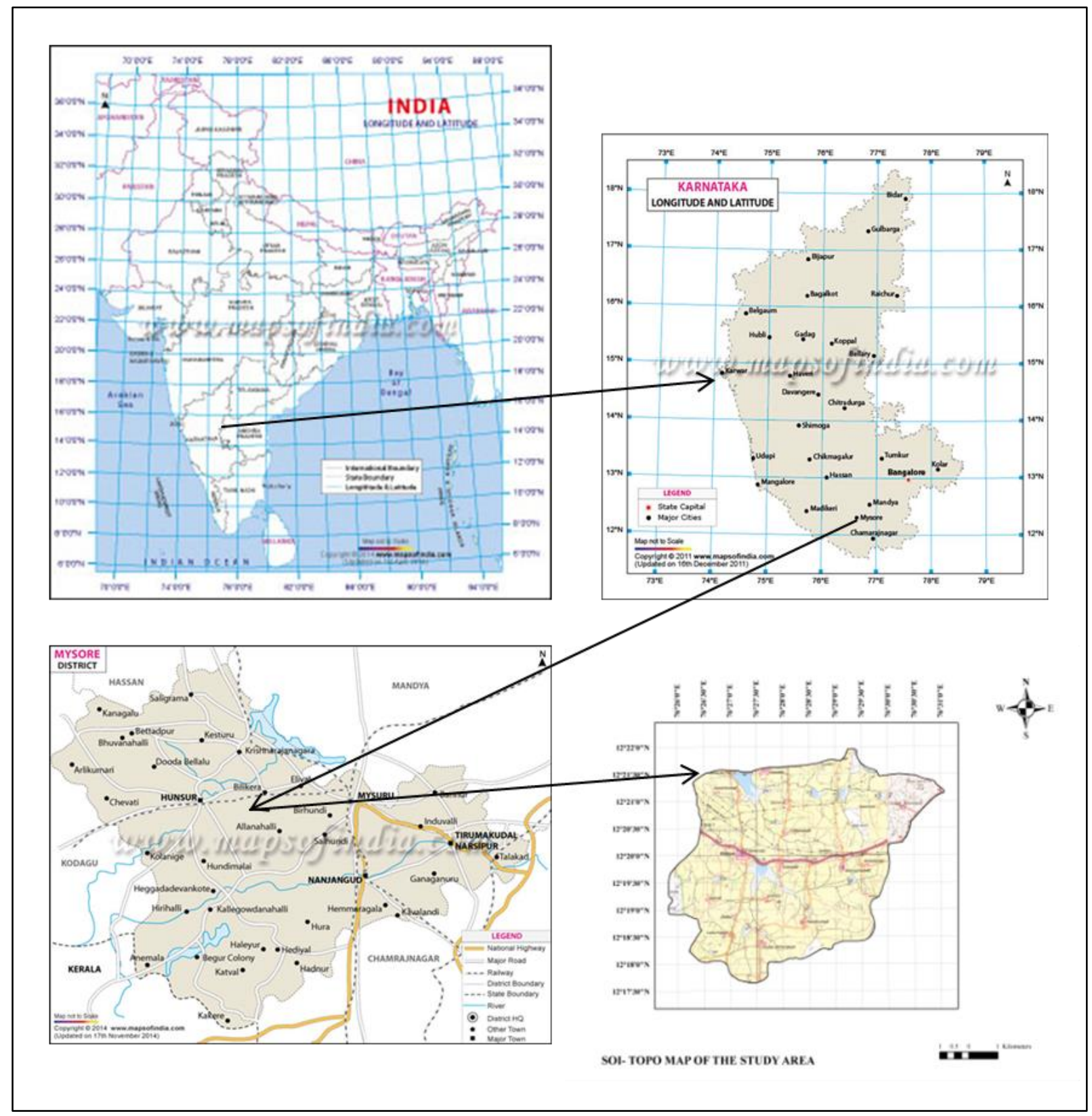

Figure 1: location of the study area 


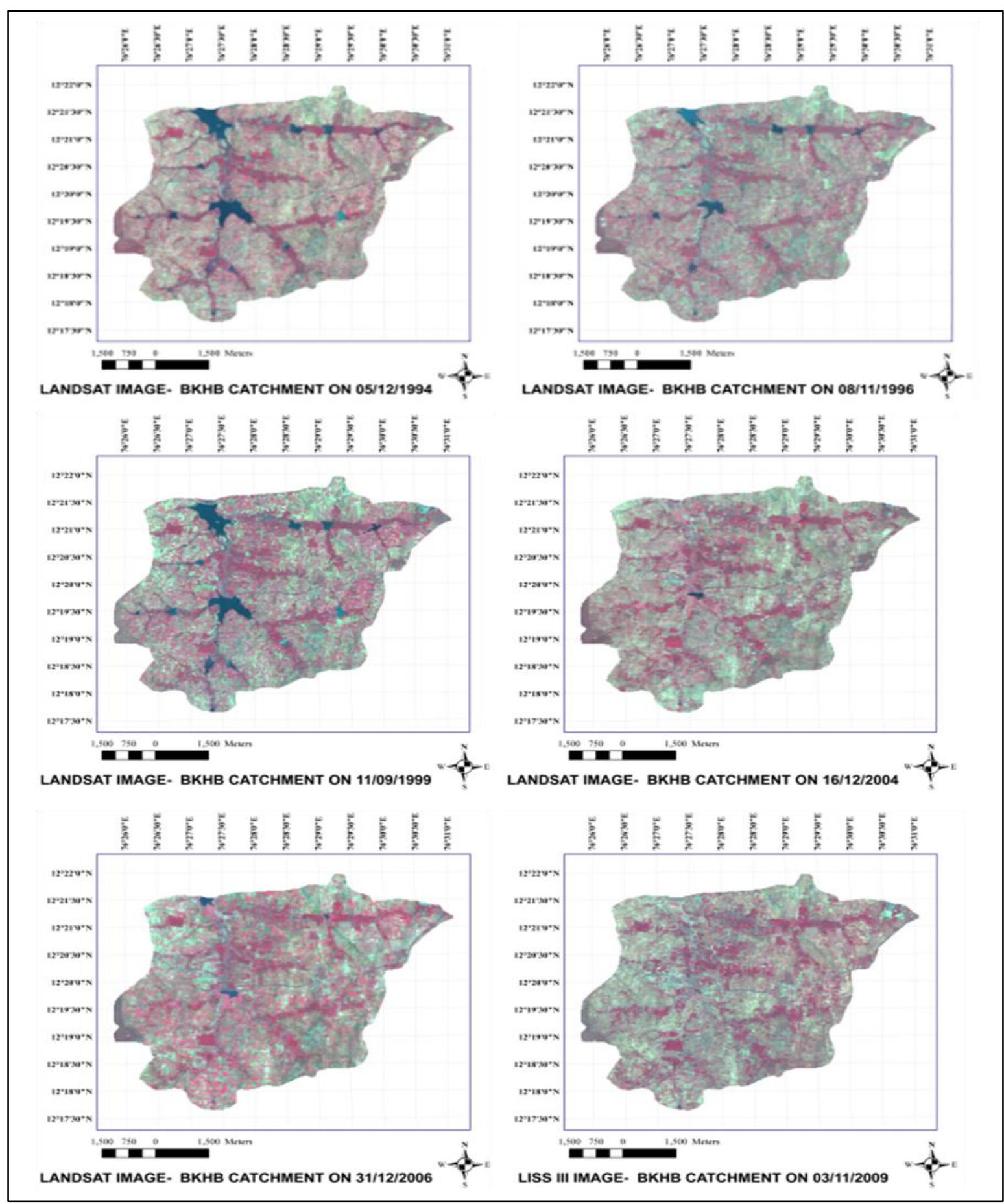

Figure 2: Temporal satellite images of the study area

\section{Data and Methodology}

The daily rainfall from 1975-2014 for Hunsur taluk of Mysore district is used for the analysis. The data is collected from Karnataka State Natural Disaster Monitoring Centre (KSNDMC), is analyzed with monthly, lustrum (5yr), decadal (10Yr), vicennial (20Yr), seasonal and annual time sequences, and investigated for statistical variations and trend analysis. 


\subsection{Mann-Kendall Test}

In the present investigation, the method illustrated by H.B. Mann (Mann 2016) for a set of data that is not normally distributed and a statistical test given by Kendall (Kendall 1955)(Kendall 1975) for verifying the non-linear trend are used. Mann-Kendall test is the combination of both methods which is widely used for the analysis of trend in weather sciences and meteorological time series.

The dual benefit for using this method is,

1) Rainfall data observed is not normally distributed and hence a non-parametric test is suitable.

2) The test has little response to impetuous gap due to heterogeneous time sequence.

The fundamental distinction between the parametric and non-parametric approach is that, in parametric methods, statistical distribution is considered whereas non-parametric methods are free from statistical distributions. In this trend analysis null hypothesis $\left(\mathrm{H}_{0}\right)$ is described by 'no trend' in the time Sequence data and alternate hypothesis $\left(\mathrm{H}_{1}\right)$ is considered as 'increasing or decreasing monotonic trend' in the time series. The Mann-Kendall (MK) test statistic ' $\mathrm{S}$ ' is determined using the following equation

$S=\sum_{k=1}^{n-1} \sum_{j=k+1}^{n} \operatorname{sgn}\left(x_{j}-x_{k}\right)$

Where $x_{j}$ and $x_{k}$ are the annual values in years ' $j$ ' and ' $k$ ' $(j>k)$ respectively, and ' $n$ ' is the number of data values. The signum function; $\operatorname{sgn}\left(\mathrm{x}_{\mathrm{j}}-\mathrm{X}_{\mathrm{k}}\right)$ is calculated as follows

$\operatorname{sgn}(x j-x k)=\left\{\begin{array}{c}1 \text { if }(x j-x k)>0 \\ 0 \text { if }(x j-x k)=0 \\ -1 \text { if }(x j-x k)<0\end{array}\right.$

If ' $\mathrm{n}$ ' is lower than 10 , then $\mathrm{MK}$ test statistic ' $\mathrm{S}$ ' is correlated directly to the theoretical distribution. Increasing trend is identified by the positive result of ' $\mathrm{S}$ ' and negative value indicated decreasing trend (Salmi et.al-2002). If ' $n$ ' is greater than or equal to 10 , then ' $S$ ' is nearly in normal distribution with the mean $\mathrm{E}(\mathrm{S})=0$ and the variance of ' $\mathrm{S}$ ' is given by

$$
\operatorname{var}(S)=\frac{n(n-1)(2 n+5)-\sum_{p=1}^{q} t_{p}\left(t_{p}-1\right)\left(2 t_{p}+5\right)}{18}
$$

Where $q$ is the number of tied groups and $t_{p}$ is the number of data values in the $\mathrm{p}^{\text {th }}$ group. The results of ' $\mathrm{S}$ ' and ' $\operatorname{var}(\mathrm{S})$ ' are used to calculate the test statistic ' $\mathrm{Z}_{\mathrm{C}}$ ' as follows

$Z_{c}= \begin{cases}\frac{s-1}{\sqrt{\operatorname{var}(S)}} & \text { if } S>0 \\ 0 & \text { if } S=0 \\ \frac{s+1}{\sqrt{\operatorname{var}(S)}} & \text { if } S<0\end{cases}$ 
The results of ' $\mathrm{Z}_{\mathrm{c}}$ ' statistics are interpreted as increasing trend with positive values and decreasing trend with negative values. Significance level ' $\alpha$ ' is used for testing either an increasing or decreasing monotone trend (a two-tailed test). At significant level ' $\alpha$ ', $Z_{c} \geq Z_{\alpha / 2}$, then the trend is considered as significant. The $Z_{c}$ values are tested at $95 \%$ level of significance.

\subsection{Sen's Slope Estimator}

It is a non-parametric method of regression analysis[17], assuming that it follows a linear trend of the form $f(t)=Q t+B$, where ' $\mathrm{Q}$ ' is the trend given by the slope in unit time, ' $\mathrm{B}$ ' is the intercept and ' $\mathrm{t}$ ' is the time. In this study rainfall is taken as the dependent variable and time is considered as the independent variable. The rate of increase/decrease in the variable is analyzed by the slope of the simple least-square regression line. The slope ' $Q$ ' is calculated using the formula

$Q_{i}=\frac{x_{j}-x_{k}}{j-k}$

where $\mathrm{x}_{\mathrm{j}}$ and $\mathrm{x}_{\mathrm{k}}$ are data values at time $\mathrm{j}$ and $\mathrm{k}(\mathrm{j}>\mathrm{k})$ respectively. If there are $\mathrm{n}$ values $\mathrm{x}_{\mathrm{j}}$ and in the time sequence, there will be as many as $N=n(n-1) / 2$ slope estimates $\mathrm{Q}_{\mathrm{i}}$. The $\mathrm{N}$ values of $\mathrm{Qi}$ are ranked from the smallest to the largest and the Sen's estimator is

$Q=\left\{\begin{array}{lr}Q_{\frac{N+1}{2}}, & \text { If } N \text { is odd } \\ \frac{1}{2}\left(Q_{\frac{N}{2}}+Q_{\frac{N+1}{2}}\right), & \text { if } N \text { is even }\end{array}\right.$

An assessment of ' $\mathrm{B}$ ' in equation $f(t)$ is made by calculating the ' $\mathrm{n}$ ' values of difference $\left(\mathrm{x}_{\mathrm{i}}-\mathrm{Q}_{\mathrm{i}}\right)$. The median of these values gives an estimate of $B$. In this investigation, the excel template application MAKESENS 1.0 is used for the computation of the Mann-Kendall statistics 'S', Sen's slope Q and intercept B.

\section{Results and Discussion}

\subsection{Trend of Annual Rainfall}

Analysis of four-decade (40) years (1975-2014) data reveals that the average annual rainfall (a.a.r) of Hunsur taluk was $802.37 \mathrm{~mm}$ which is slightly higher than the mean rainfall of the Mysore district $(770 \mathrm{~mm})$. The minimum a.a.r of $100 \mathrm{~mm}$ was in 2012 and a maximum a.a.r of $1416 \mathrm{~mm}$ in 1999. Excess precipitation $(>962.8 \mathrm{~mm})$ occurred in 8 years out of 40 years, deficient rainfall occurred in 5 years out of 40 years, scanty rainfall occurred in 2012(-88\%). Normal rainfall (range $649.9 \mathrm{~mm}$ to $954.82 \mathrm{~mm}$ ) occurred in 26years among 40 years indicating that the a.a.r is normal in the taluk as shown in Figure 3.

The analysis carried using MAKESENS 1.0 reveals that, there is 'NO' trend for January, February and March. 'Decreasing trend' is observed for April, May, July, September and November. 'Increasing trend' is noticed for June, October, and December. Very significant change is observed for the month of August (95\% significance level). Also it is observed that Pre-Monsoon and Southwest monsoon rainfall are in declining trend and North-East monsoon and annual rainfall trend is 
on the rising trend. Sen's slope estimator calculation shows no change in the trend for January, February, March and December; for the month of June, a very insignificant positive trend; and for August and October; there is a significant increasing trend. For April, May, July, September and November a negligible negative trend is observed. The annual and NE-monsoon trend is marginally in increasing trend and both SW-monsoon and Pre-monsoon rainfall is in the negative trend (Refer Table 1).

From Figure 4, it is observed that the Sen's slope estimate is nearly parallel to the $\mathrm{x}$-axis which suggests that the a.a.r is more consistent. Confidence interval at $99 \%$ and $95 \%$ are also plotted and implies that the annual rainfall is uniform.

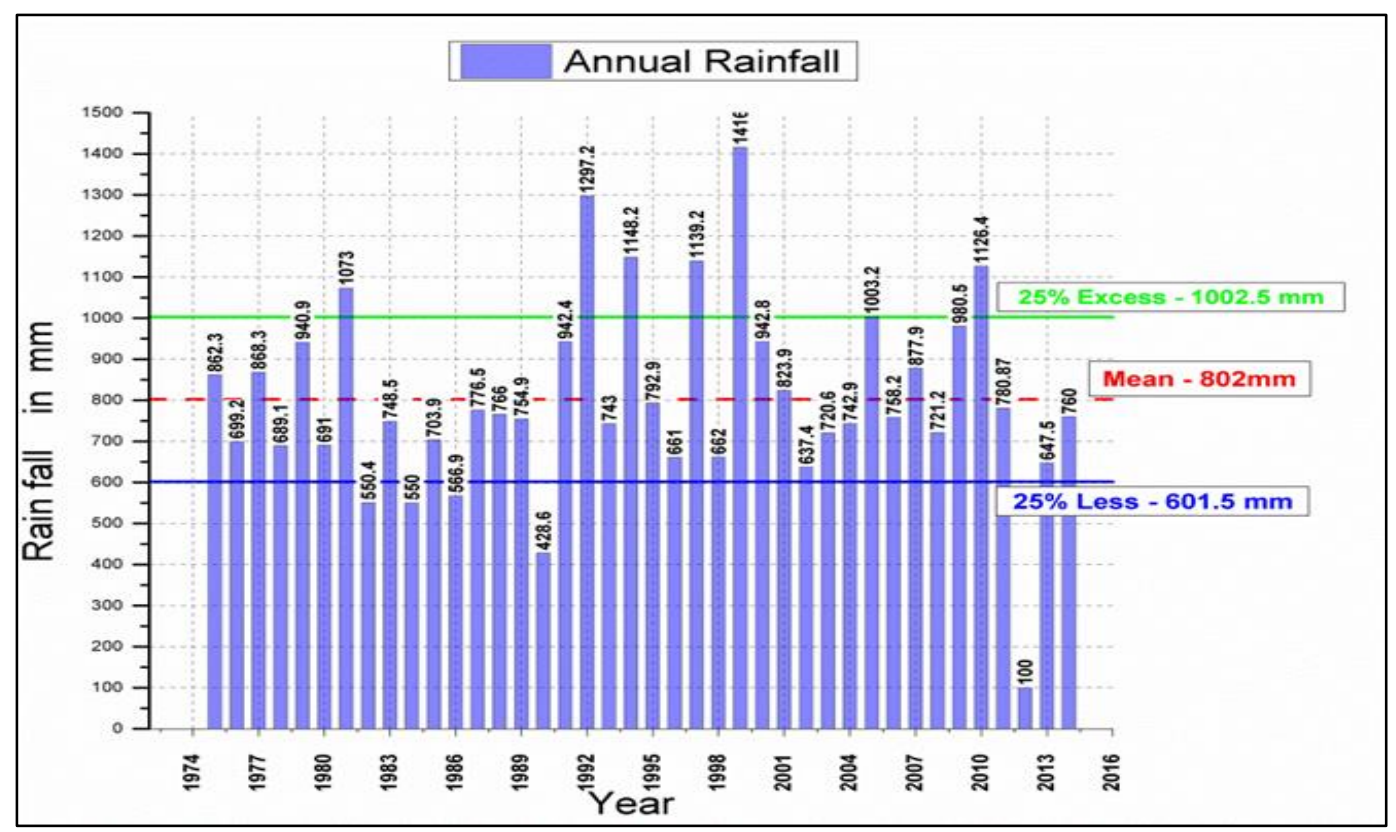

Figure 3: Average annual rainfall in Hunsur taluk (1975-2014)

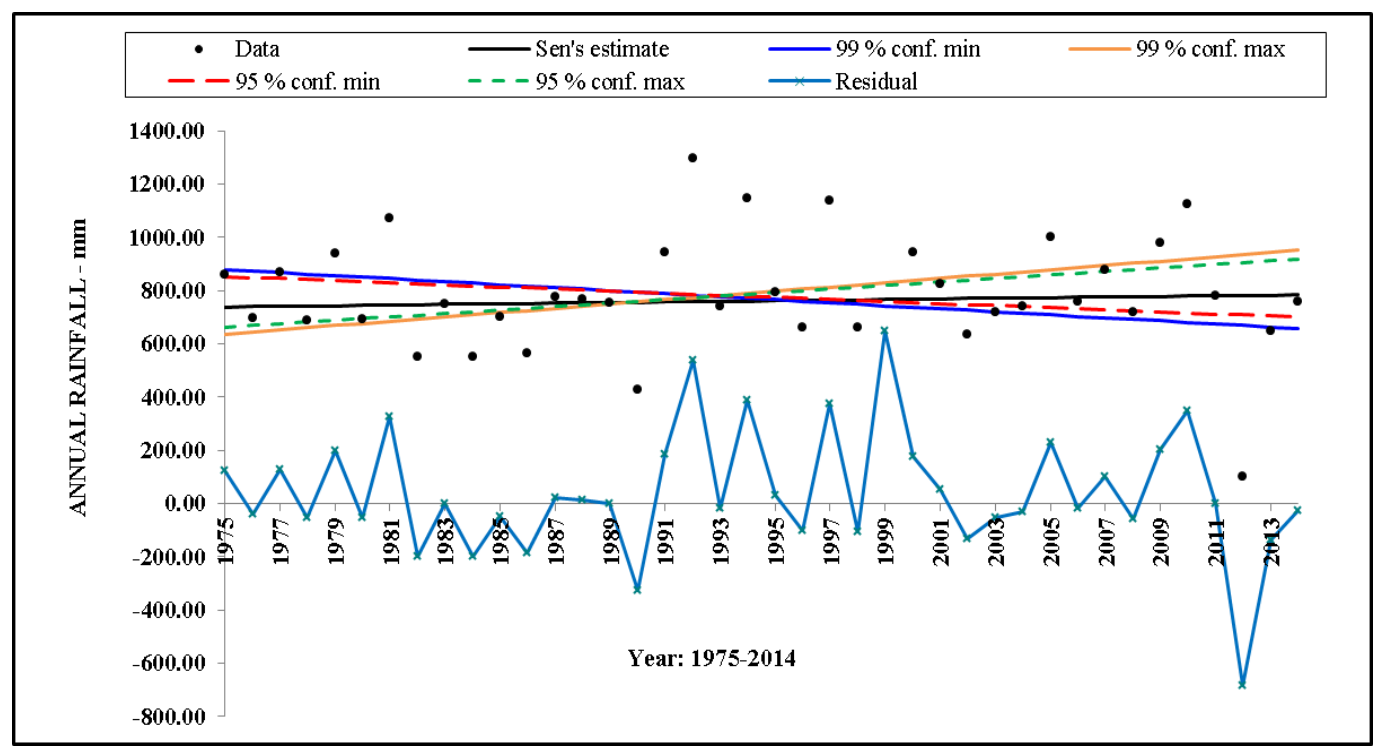

Figure 4: Trend of annual rainfall in Hunsur taluk (1975-2014) 
Table 1: Mann-Kendall and Sen's slope estimator results 1975-2014

\begin{tabular}{|l|l|l|l|l|l|l|}
\hline & \multicolumn{4}{|l|}{ Mann-Kendall Test statistic } & \multicolumn{2}{l|}{ Sen's estimator of slope } \\
\hline Time series & First year & Last Year & n & Test Z & Q & B \\
\hline January & 1975 & 2014 & 40 & 0.00 & 0.00 & 0.00 \\
\hline February & 1975 & 2014 & 40 & 0.00 & 0.00 & 0.00 \\
\hline March & 1975 & 2014 & 40 & 0.00 & 0.00 & 0.00 \\
\hline April & 1975 & 2014 & 40 & -0.373 & -0.269 & 64.470 \\
\hline May & 1975 & 2014 & 40 & -0.559 & -0.519 & 101.330 \\
\hline June & 1975 & 2014 & 40 & 0.093 & 0.019 & 80.987 \\
\hline July & 1975 & 2014 & 40 & -0.419 & -0.351 & 94.167 \\
\hline August & 1975 & 2014 & 40 & $\mathbf{1 . 9 8 1}$ & $\mathbf{1 . 4 1 7}$ & $\mathbf{4 1 . 3 8 6}$ \\
\hline September & 1975 & 2014 & 40 & -0.920 & -1.226 & 133.378 \\
\hline October & 1975 & 2014 & 40 & 1.410 & 1.585 & 106.088 \\
\hline November & 1975 & 2014 & 40 & -0.746 & -0.340 & 49.449 \\
\hline December & 1975 & 2014 & 40 & 1.048 & 0.000 & 0.000 \\
\hline PRE_MONSOON & 1975 & 2014 & 40 & -0.233 & -0.382 & 184.50 \\
\hline SW_MONSOON & 1975 & 2014 & 40 & -0.291 & -0.528 & 369.592 \\
\hline NE_MONSOON & 1975 & 2014 & 40 & 0.524 & 0.832 & 195.658 \\
\hline ANNUAL & 1975 & 2014 & 40 & 0.594 & 1.163 & 738.819 \\
\hline
\end{tabular}

\subsection{Trend of Vicennial Rainfall: (20 Year period)}

The forty year data from 1975-2014 is divided into 2 parts i.e. from 1975-1994 as first vicennium and 1995-2014 as second vicennium. The first vicennium analysis shows that the average annual rainfall (a.a.r) of Hunsur taluk was $790.02 \mathrm{~mm}$ which is little higher than the mean rainfall of the district $(770 \mathrm{~mm})$. The minimum a.a.r of $426.8 \mathrm{~mm}$ was in 1990 and a maximum a.a.r of 1297.2 $\mathrm{mm}$ in 1992. Excess precipitation $(>962.8 \mathrm{~mm})$ appeared in 3 years out of 20 years, Deficient rainfall appeared in 4 years out of 20 years, scanty rainfall is not observed in the period. Normal rainfall (range $649.9 \mathrm{~mm}$ to $954.82 \mathrm{~mm}$ ) occurred in 13 years among 20 years indicating that the a.a.r is normal in the taluk as shown in Table 2 and Figure 5 whereas second vicennium study discloses that, the average annual rainfall (a.a.r) of Hunsur taluk was $814.72 \mathrm{~mm}$ which is little higher than the mean rainfall of the district $(770 \mathrm{~mm})$ and first vicennium. The minimum a.a.r of $100 \mathrm{~mm}$ was in 2012 and a maximum a.a.r of $1416 \mathrm{~mm}$ in 1999. Excess precipitation (>962.8mm) occurred in 5 years out of 20 years, Deficient rainfall occurred in 1 year out of 20 years, scanty rainfall occurred only once in the year 2012. Normal rainfall (range 649.9mm to $954.82 \mathrm{~mm}$ ) occurred in 13years among 20 years indicating that the a.a.r is normal in the taluk as shown in Table 2 and Figure 6.

The trend statistics ' $Z$ ' values of Mann-Kendall test for the first vicennium tells that all the months and seasons of the year has the increasing trend except for the months of April, September and November. Whereas for the second vicennium, the figures of ' $Z$ ' shown in Table 2 highlights that most of the months and seasons show a negative trend other than the months of February, March, May and October. There is no significant change in the trend for any of the months and seasons. 


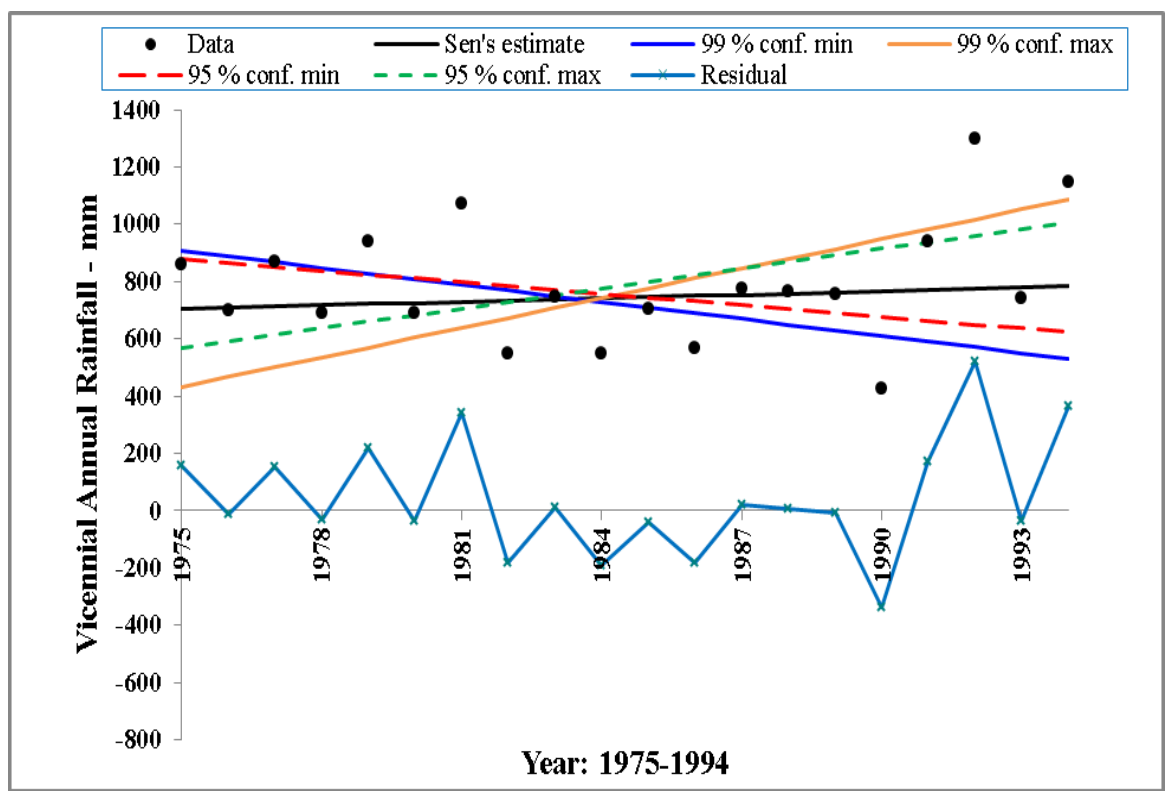

Figure 5: Vicennium variation of a.a.r (75-94)

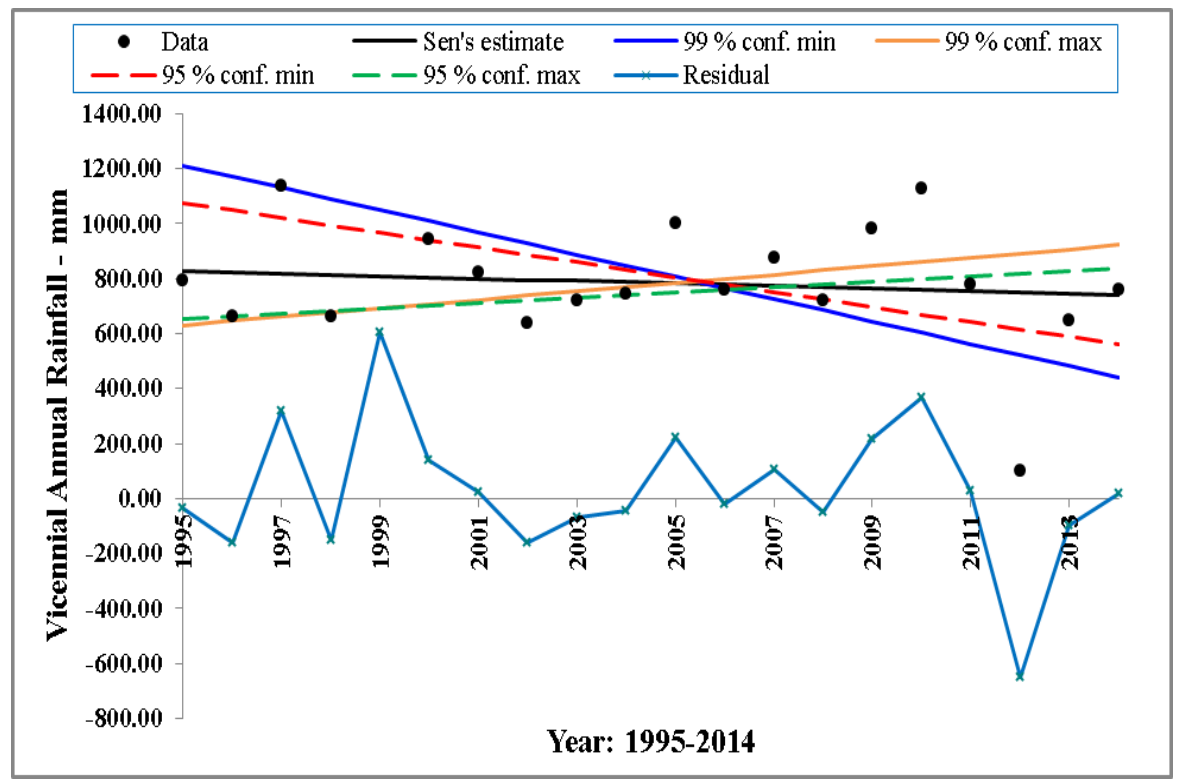

Figure 6: Vicennium variation of a.a.r (95-14)

Table 2: Trend analysis of vicennial rainfall

\begin{tabular}{|l|l|l|l|l|l|l|}
\hline & \multicolumn{3}{|l|}{ I-Vicenniun-1975-1994 } & \multicolumn{3}{l|}{ II-Vicennium-1995-2014 } \\
\hline Time series & Test Z & Q & B & Test Z & Q & B \\
\hline Jan & 0.4739 & 0.0000 & 0.0000 & -0.7250 & 0.0000 & 0.0000 \\
\hline Feb & 0.0000 & 0.0000 & 0.0000 & 0.6997 & 0.0000 & 0.0000 \\
\hline Mar & 1.1502 & 0.0000 & 0.0000 & 1.0092 & 0.0541 & 1.7575 \\
\hline Apr & -0.9738 & -1.8000 & 67.1000 & -0.9089 & -1.9605 & 78.1630 \\
\hline May & 0.7791 & 1.4652 & 89.3612 & 0.4867 & 1.3993 & 73.5054 \\
\hline Jun & 0.8440 & 2.2716 & 72.5702 & -0.7462 & -0.9814 & 88.7018 \\
\hline
\end{tabular}




\begin{tabular}{|l|l|l|l|l|l|l|}
\hline Jul & 0.6813 & 1.3443 & 86.0511 & -0.4867 & -0.7221 & 90.6598 \\
\hline Aug & 0.9089 & 1.4366 & 32.0059 & -0.4867 & -1.3832 & 112.3560 \\
\hline Sep & -1.2004 & -3.4833 & 138.4083 & -0.8760 & -3.4424 & 144.6380 \\
\hline Oct & 1.0058 & 4.7417 & 82.5333 & 0.0324 & 0.4467 & 151.7697 \\
\hline Nov & -0.4218 & -0.8643 & 59.8893 & -0.4218 & -0.2333 & 38.8333 \\
\hline Dec & 0.6513 & 0.0000 & 0.0000 & -0.8405 & 0.0000 & 7.0000 \\
\hline PRE_MONSOON & 0.1298 & 0.2233 & 168.5633 & -0.0324 & -0.4378 & 200.1254 \\
\hline SW_MONSOON & 0.1622 & 2.6722 & 346.4639 & -1.3951 & -3.1400 & 377.6100 \\
\hline NE_MONSOON & 0.2271 & 0.6775 & 190.8025 & -0.8111 & -3.4093 & 255.3885 \\
\hline ANNUAL & 0.6813 & 4.0625 & 705.6063 & -0.4867 & -4.6092 & 828.2379 \\
\hline
\end{tabular}

\subsection{Trend of Decadal Rainfall: 10 (Year Period)}

In this assessment, the data is split into four groups of each 10 year (Decadal) span. Table $3 \& 4$ and Figure 7-10, shows a comparison of Mann-Kendall test ' $Z$ ' value and Sen's Estimator values of ' $Q$ ' and ' $B$ '. In the first decade from 1975-1984, it is seen that there is a falling trend for January, April, May, September, October and November indicating that the pre-monsoon and NE-monsoon rain is as well in the decreasing trend. The second decade from 1985-1994 has most of the months in the increasing trend except for March, April, September, November and December signifying that the trend for monsoon rainfall is increasing in this period including the annual rainfall. The third and the fourth decadal results show that a sudden and significant decreasing trend in the SWmonsoon and annual rainfall. May be this is one of the reason for the degradation of the lakes in the study area.

The decadal ' $Z$ ' values for annual rainfall plotted as shown in Figure 11. It shows NE-Monsoon is in the increasing trend and all other seasons including annual rainfall is in the decreasing trend. The equation for the regression is also shown in the Figure 11. Bold values show significant (95\%) trend values. '+' values indicate increasing trend and '-' value indicates decreasing trend.

Table 3: Decadal statistical data from 1975-84 \& 1985-94.

\begin{tabular}{|l|l|l|l|l|l|l|}
\hline & \multicolumn{3}{|c|}{ Decade I; 1975-1984 } & \multicolumn{3}{l|}{ Decade II ; 1985-1994 } \\
\hline Time series & Test Z & Q & B & Test Z & Q & B \\
\hline Jan & -1.39 & 0.00 & 0.00 & 1.04 & 0.00 & 0.00 \\
\hline Feb & 0.33 & 0.00 & 0.00 & 0.78 & 0.00 & 0.00 \\
\hline Mar & 1.57 & 0.00 & 0.00 & -0.10 & 0.00 & 0.00 \\
\hline Apr & -0.99 & -5.93 & 90.31 & -0.54 & -1.80 & 42.60 \\
\hline May & -1.35 & -9.12 & 132.14 & 1.61 & 9.00 & 58.60 \\
\hline Jun & 0.45 & 4.33 & 70.24 & $\mathbf{1 . 9 7}$ & $\mathbf{1 3 . 6 3}$ & $\mathbf{2 6 . 8 5}$ \\
\hline Jul & 1.25 & 9.85 & 54.10 & 1.43 & 12.94 & 47.07 \\
\hline Aug & 0.36 & 4.36 & 32.77 & 1.61 & 5.01 & 29.09 \\
\hline Sep & -0.36 & -8.01 & 176.10 & -1.07 & -7.70 & 136.65 \\
\hline Oct & -0.18 & -2.12 & 109.98 & 1.07 & 9.56 & 101.91 \\
\hline Nov & $\mathbf{- 1 . 7 9}$ & $\mathbf{- 1 1 . 0 0}$ & 99.00 & -0.18 & -2.78 & 70.00 \\
\hline Dec & 0.52 & 0.00 & 0.00 & -0.77 & 0.00 & 1.00 \\
\hline PRE_MONSOON & -1.35 & -10.78 & 227.05 & 1.25 & 8.33 & 137.17 \\
\hline
\end{tabular}




\begin{tabular}{|l|l|l|l|l|l|l|}
\hline SW_MONSOON & 0.18 & 2.93 & 369.63 & 1.25 & 26.47 & 253.22 \\
\hline NE_MONSOON & $\mathbf{- 1 . 7 9}$ & $\mathbf{- 1 3 . 5 7}$ & 259.27 & 0.54 & 19.38 & 137.98 \\
\hline ANNUAL & -0.89 & -19.97 & 826.57 & 1.25 & 49.37 & 632.05 \\
\hline
\end{tabular}

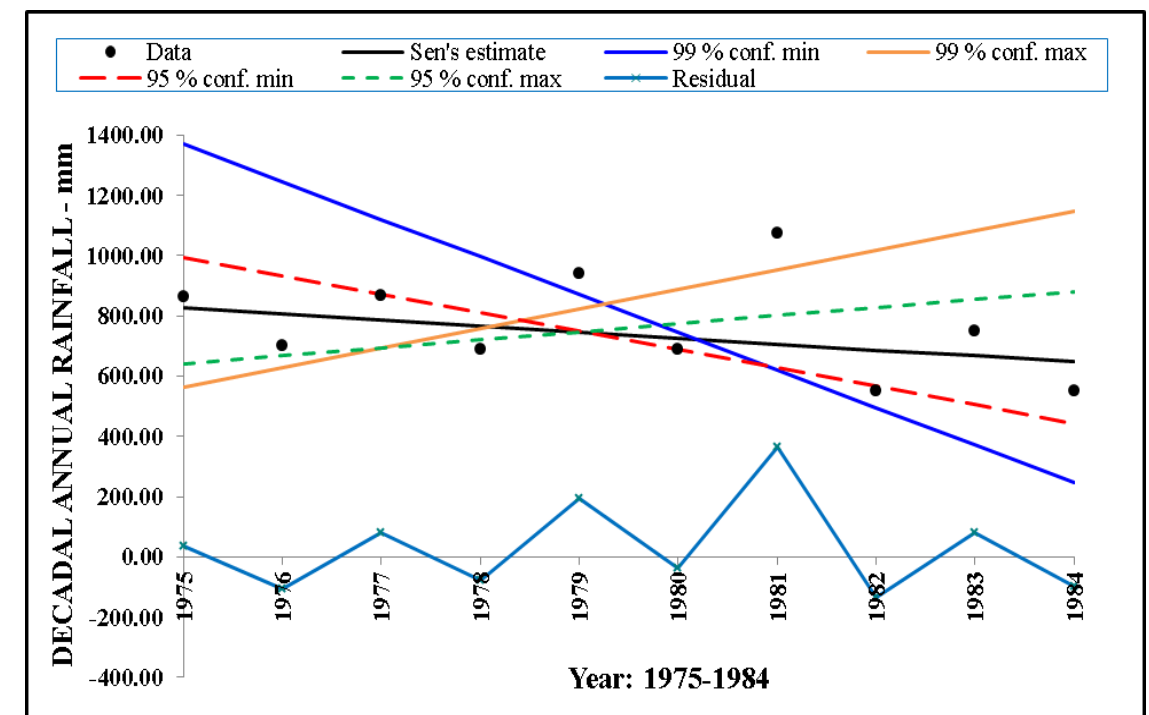

Figure 7: Decadal variations of a.a.r (75-84)

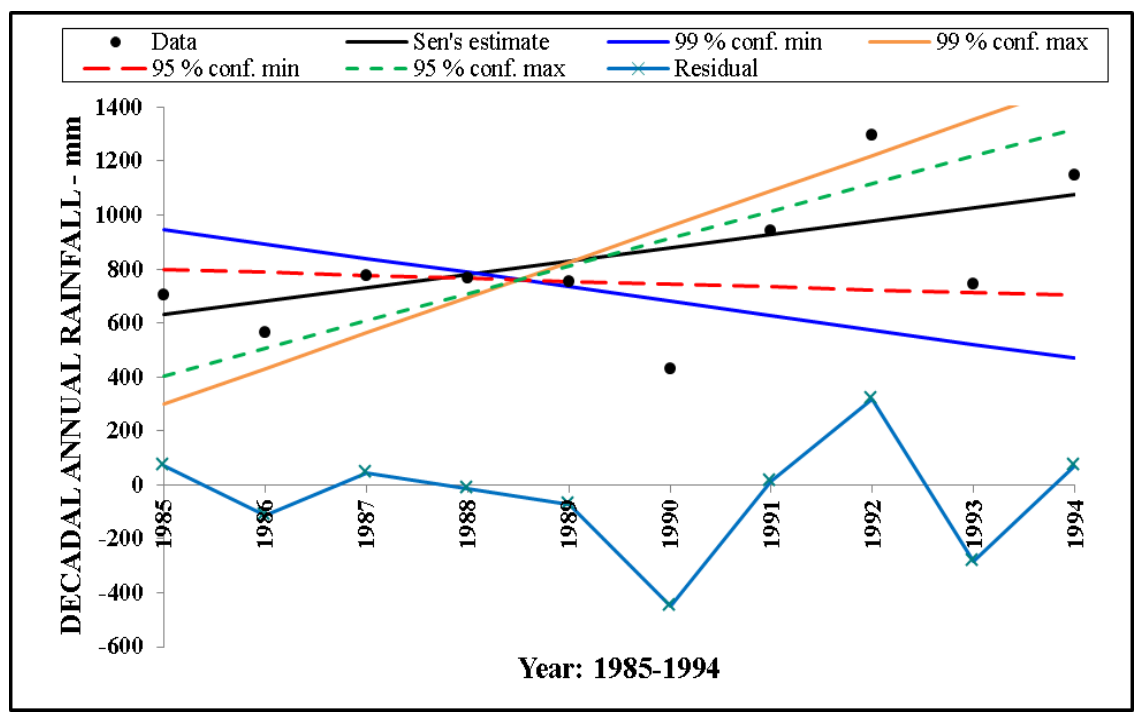

Figure 8: Decadal variations of a.a.r (85-94)

Table 4: Decadal statistical data from 1995-04 \& 2005-14.

\begin{tabular}{|l|l|l|l|l|l|l|}
\hline & \multicolumn{3}{|c|}{ Decade III; 1995-2004 } & \multicolumn{3}{|c|}{ Decade IV; 2005-2014 } \\
\hline Time series & Test Z & Q & B & Test Z & Q & B \\
\hline Jan & -0.78 & 0.00 & 0.00 & -1.00 & 0.00 & 0.00 \\
\hline Feb & 0.00 & 0.00 & 0.00 & 1.35 & 0.14 & -0.07 \\
\hline Mar & 0.51 & 0.00 & 0.00 & -0.72 & -0.83 & 8.43 \\
\hline Apr & 0.00 & 0.56 & 61.44 & -1.43 & -6.96 & 83.57 \\
\hline May & 0.00 & -0.63 & 54.40 & -0.72 & -4.08 & 134.09 \\
\hline
\end{tabular}




\begin{tabular}{|l|l|l|l|l|l|l|}
\hline Jun & -0.72 & -1.31 & 78.00 & $\mathbf{- 1 . 7 9}$ & $\mathbf{- 9 . 2 3}$ & $\mathbf{1 2 3 . 6 5}$ \\
\hline Jul & -0.89 & -3.20 & 102.85 & $\mathbf{- 2 . 3 3}$ & $\mathbf{- 7 . 5 2}$ & $\mathbf{1 3 3 . 3 1}$ \\
\hline Aug & -0.36 & -2.10 & 96.70 & -0.72 & -5.00 & 116.00 \\
\hline Sep & -0.18 & -4.80 & 172.00 & 0.18 & 1.50 & 95.25 \\
\hline Oct & 0.18 & 3.93 & 130.85 & 0.00 & 0.83 & 158.38 \\
\hline Nov & -1.07 & -4.40 & 59.10 & -0.89 & -7.60 & 91.45 \\
\hline Dec & -1.30 & -1.87 & 16.80 & 0.00 & 0.00 & 6.05 \\
\hline PRE_MONSOON & 0.00 & 2.50 & 176.30 & -1.07 & -18.56 & 302.43 \\
\hline SW_MONSOON & $\mathbf{- 2 . 3 3}$ & $\mathbf{- 9 . 4 8}$ & $\mathbf{4 1 3 . 9 1}$ & -1.07 & -19.16 & 498.69 \\
\hline NE_MONSOON & 0.00 & -0.60 & 239.10 & 0.00 & -5.08 & 228.10 \\
\hline ANNUAL & -0.36 & -6.15 & 795.58 & -1.07 & -24.26 & 926.42 \\
\hline
\end{tabular}

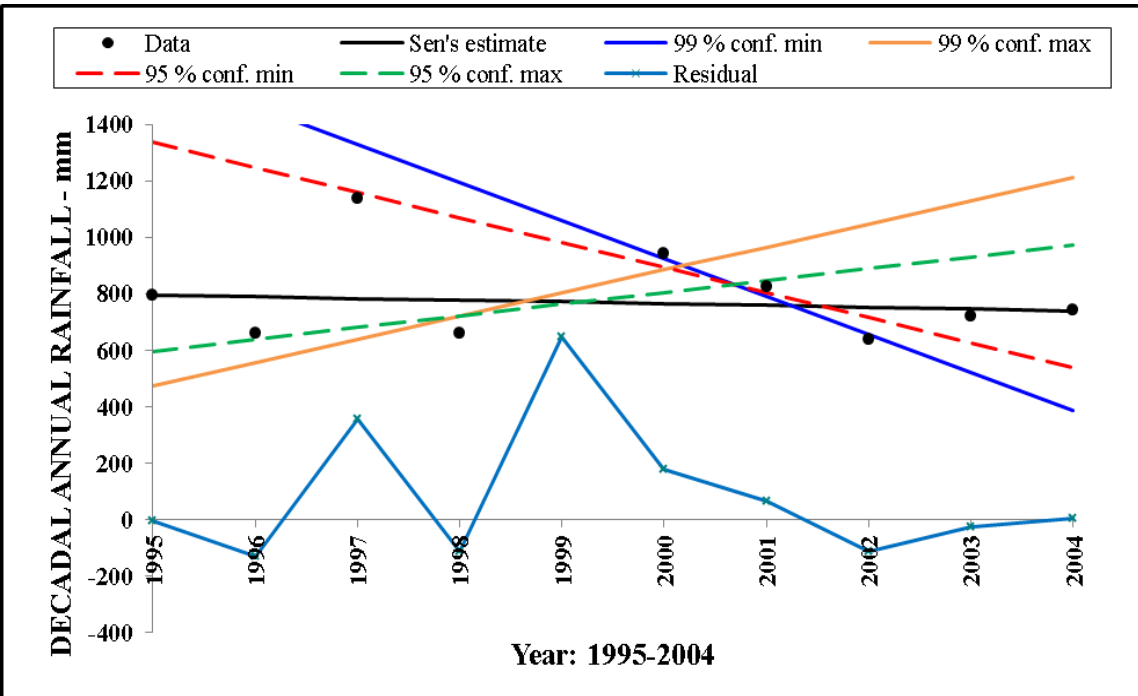

Figure 9: Decadal variations of a.a.r (95-04)

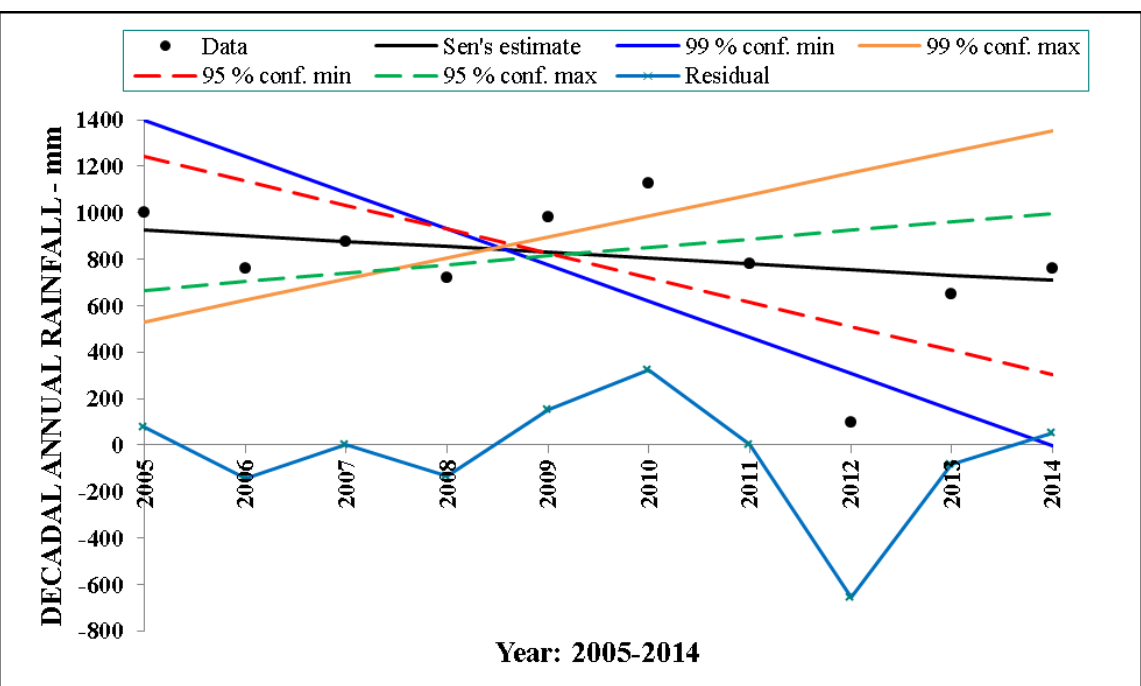

Figure 10: Decadal variations of a.a.r (05-14) 


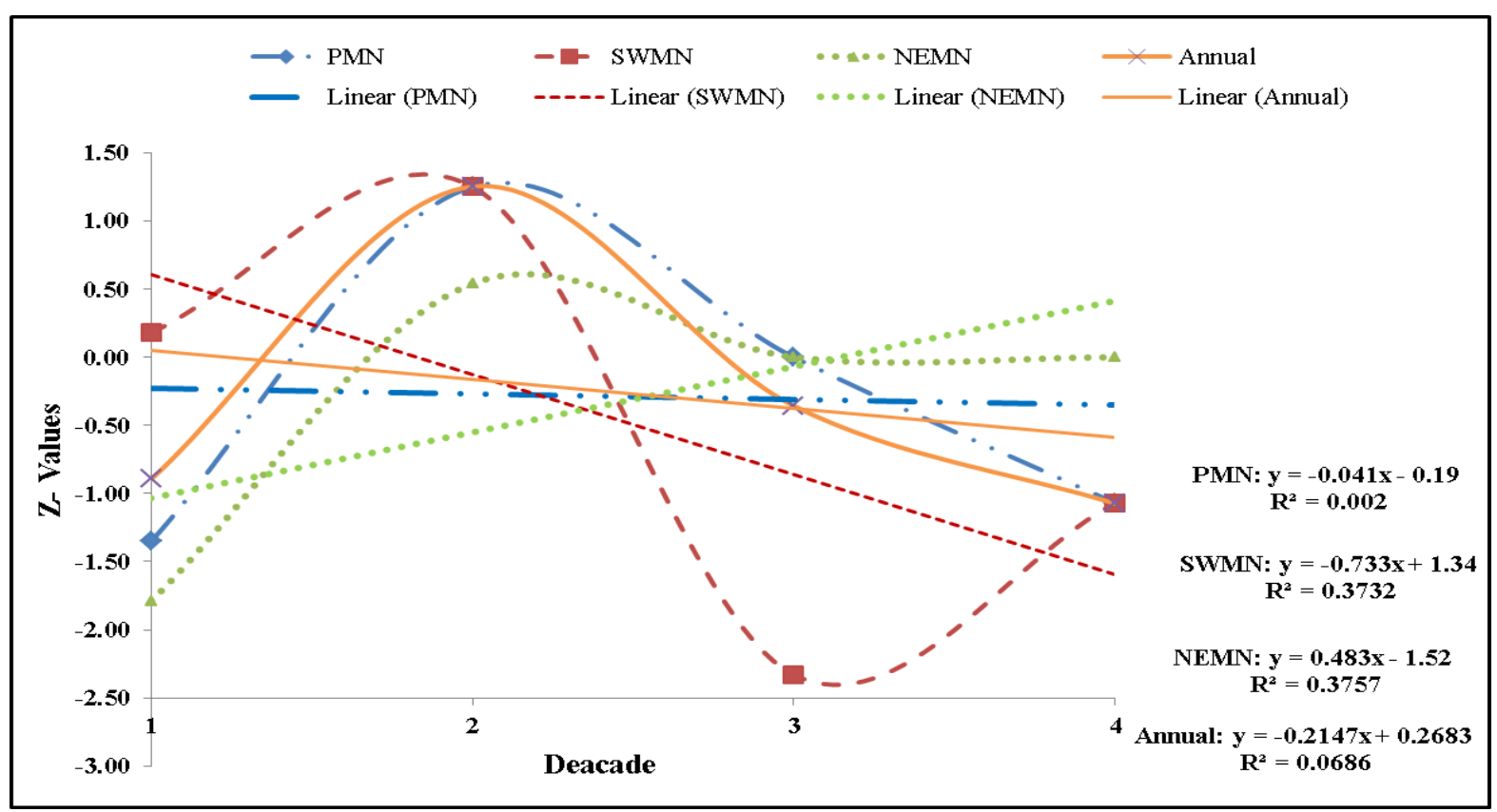

Figure 11: 'Z' statistic value against Decade period.

\subsection{Lustra Analysis (5Year period)}

To evaluate that the trend of rainfall, especially the monsoon seasons and months was decreasing in the recent period which may be one of the governing factors for the drying of waterbodies in the study area. The forty year data is subdivided into 8 groups of five (5) year span and analyzed for the Mann-Kendall test 'S' $(\mathrm{n}<10)$ values, Sen's estimator ' $\mathrm{Q}$ ' and 'B' results and compared with each other as tabulated in Table 5 and Figure 12 to 19 . The results were analyzed and observed that SW-monsoon month i.e. June- September are in the decreasing trend in the latest two lustra as compared to the other lustra.

The lustrum ' $\mathrm{S}$ ' value and regression trend line indicates (Figure 20) that all seasonal and annual rainfall is in the decreasing trend.

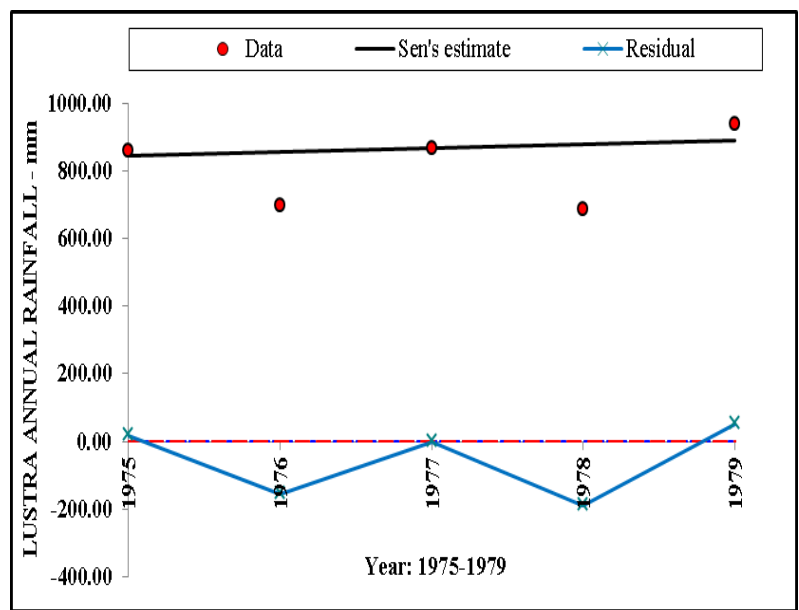

Figure 12: Lustra variation of a.a.r (75-79)

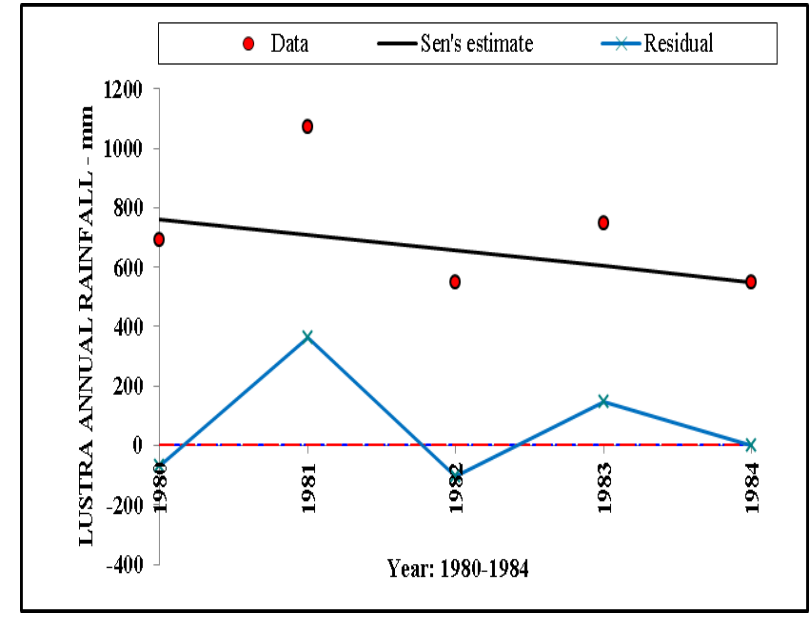

Figure 13: Lustra variation of a.a.r (80-84) 


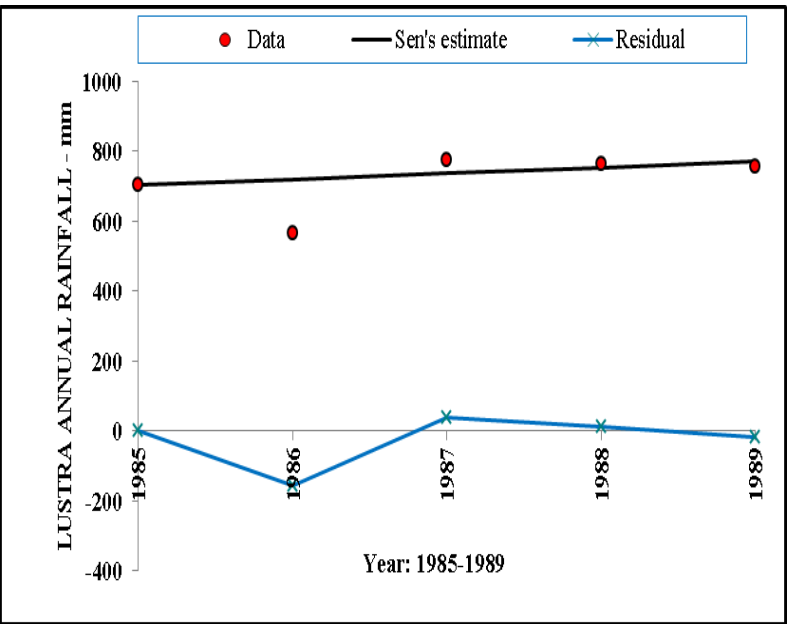

Figure 14: Lustra variation of a.a.r (85-89)

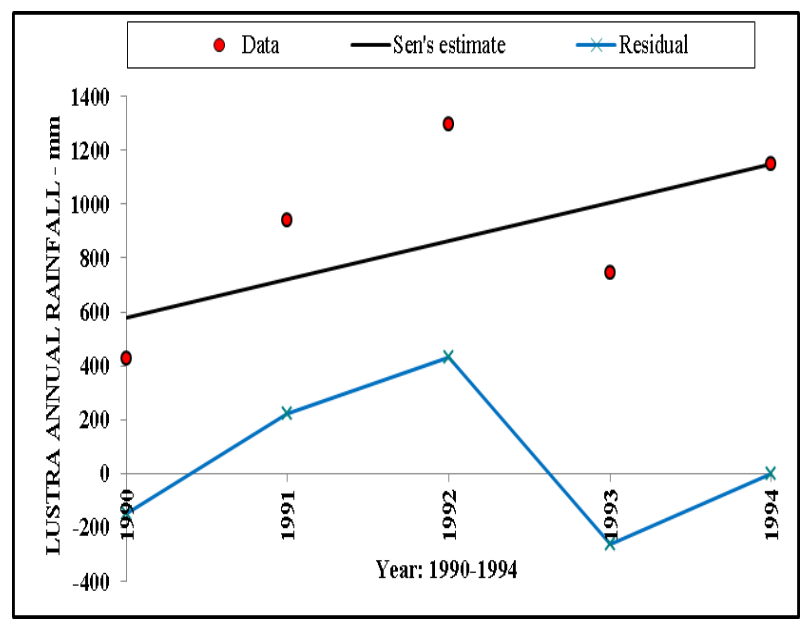

Figure 15: Lustra variation of a.a.r (90-94)

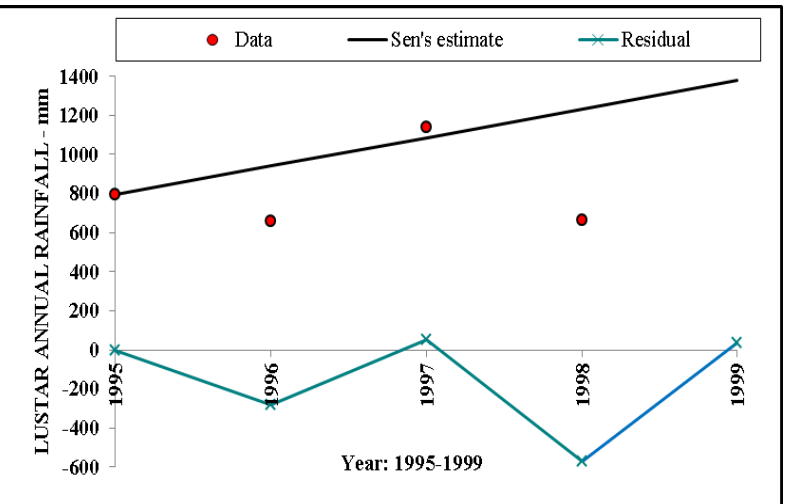

Figure 16: Lustra variation of a.a.r (95-99)

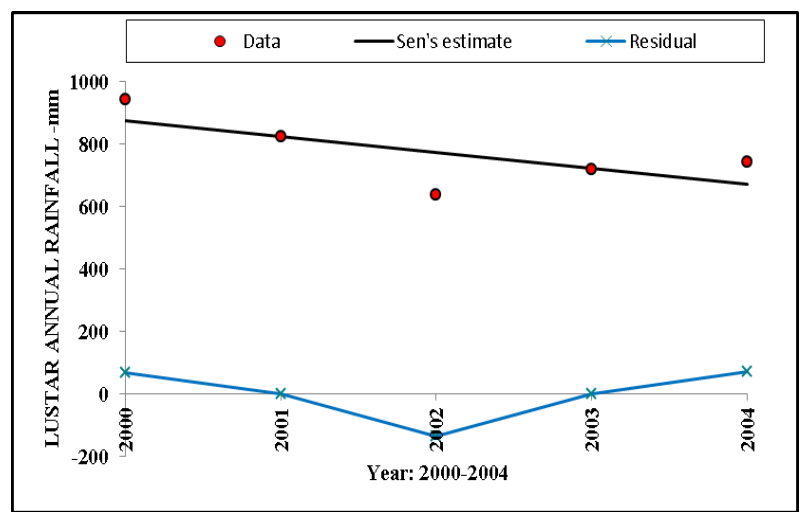

Figure 17: Lustra variation of a.a.r (00-04)

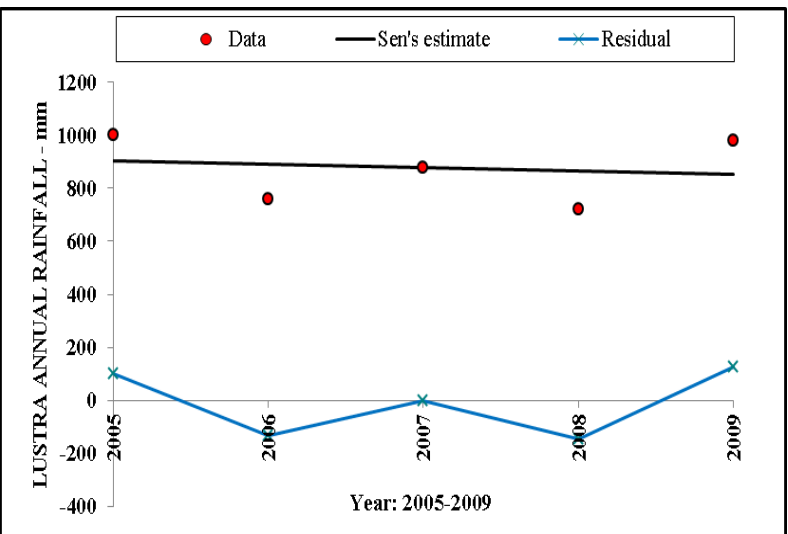

Figure 18: Lustra variation of a.a.r (05-09)

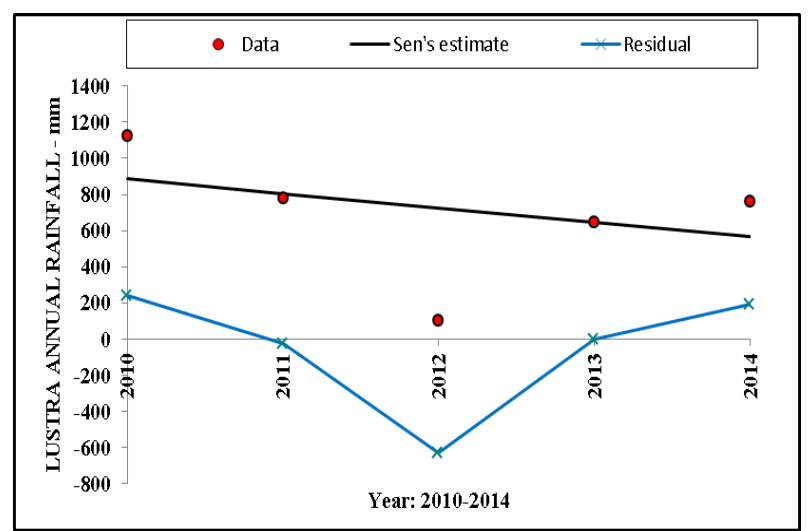

Figure 19: Lustra variation of a.a.r (10-14)

Table 5: Lustra statistical data from 1975-2014.

\begin{tabular}{|l|l|l|l|l|l|l|}
\hline \multirow{2}{*}{ Time series } & \multicolumn{4}{|l|}{$\mathbf{1 9 7 5 - 1 9 7 9}$} & \multicolumn{1}{l|}{$\mathbf{1 9 8 0 - 1 9 8 4}$} \\
\cline { 2 - 7 } & S & Q & B & S & Q & B \\
\hline Pre-monsoon & 6 & 26.51 & 151.77 & -5 & -16.72 & 188.00 \\
\hline SW-monsoon & -2 & -7.86 & 296.99 & -4 & -67.35 & 599.10 \\
\hline NE-monsoon & 0 & -2.16 & 227.49 & 0 & 1.10 & 142.00 \\
\hline
\end{tabular}




\begin{tabular}{|l|l|l|l|l|l|l|}
\hline Annual & 2 & 11.33 & 845.65 & -4 & -52.78 & 761.10 \\
\hline & $\mathbf{1 9 8 5 - 1 9 8 9}$ & \multicolumn{1}{l|}{$\mathbf{1 9 9 0 - 1 9 9 4}$} \\
\hline & $\mathbf{S}$ & $\mathbf{Q}$ & $\mathbf{B}$ & $\mathbf{S}$ & $\mathbf{Q}$ & $\mathbf{B}$ \\
\hline Pre-monsoon & 4 & 29.73 & 126.27 & 2 & 22.43 & 162.00 \\
\hline SW-monsoon & 4 & 24.75 & 283.70 & 2 & 64.58 & 209.47 \\
\hline NE-monsoon & -2 & -29.07 & 243.28 & 6 & 55.87 & 94.40 \\
\hline Annual & 2 & 16.73 & 703.90 & 4 & 142.35 & 578.80 \\
\hline & $\mathbf{1 9 9 5 - 1 9 9 9}$ & & $\mathbf{2 0 0 0 - 2 0 0 4}$ \\
\hline Pre-monsoon & 2 & 32.98 & 122.30 & 0 & -19.87 & 219.10 \\
\hline SW-monsoon & $\mathbf{- 1 0}$ & $\mathbf{- 5 1 . 1 0}$ & $\mathbf{5 1 6 . 2 0}$ & $\mathbf{- 8} *$ & $\mathbf{- 9 . 5 2}$ & $\mathbf{3 6 8 . 1 5}$ \\
\hline NE-monsoon & 6 & 143.45 & 97.50 & -4 & -18.66 & 244.00 \\
\hline Annual & 4 & 147.09 & 792.90 & -4 & -50.81 & 874.71 \\
\hline & $\mathbf{2 0 0 5 - 2 0 0 9}$ & & $\mathbf{2 0 1 0 - 2 0 1 4}$ & \\
\hline Pre-monsoon & 0 & 2.00 & 226.60 & -4 & -29.88 & 226.55 \\
\hline SW-monsoon & 2 & 8.16 & 501.60 & 0 & 6.91 & 321.76 \\
\hline NE-monsoon & -2 & -18.85 & 261.40 & -4 & -56.18 & 339.03 \\
\hline Annual & -2 & -12.09 & 902.08 & -4 & -79.14 & 884.93 \\
\hline
\end{tabular}

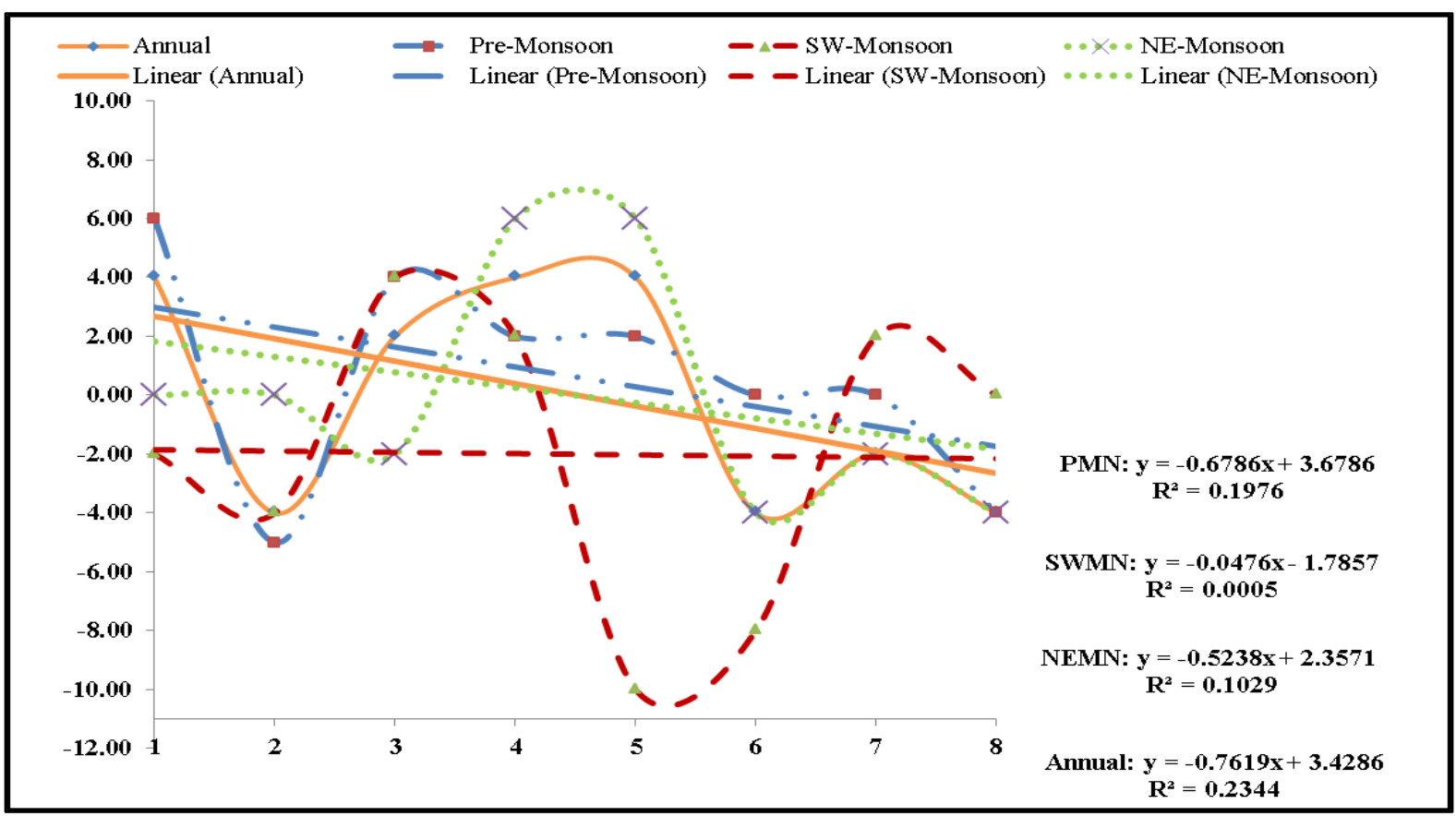

Figure 20: S' Value plotted against Lustra.

\section{Conclusions}

To ascertain the reason behind the degradation of minor irrigation tanks/lakes and to manage the water resources for small agricultural catchments, it is very essential to study and understand the rainfall trend. Daily rainfall data from 1975-2014 is analyzed using Mann-Kendall and Sen's Estimator, a non-parametric statistical approach to assess the periodical fluctuations of rainfall in Hunsur taluk of Mysore district. The study reveals the following results. 
1) Though there is an increase in annual rainfall $(1.16 \mathrm{~mm} / \mathrm{year})$, the monsoon rainfall is in decreasing trend.

2) The annual rainfall is normal (as per IMD classification - 26 out of 40 years) in the taluk

3) Vicennial study shows a there is a decreasing trend (1995-2014) in the second vicennium and increasing trend in the first vicennium (1975-1994).

4) The decadal investigation exhibits that, there is a significant decreasing trend ( $Z$ value 2.33) in the third decade (1995-2004) of the south-west monsoon and further there is a denoting fall in the rainfall for June-July in the last decade (2005-2014).

5) The trend line of ' $Z$ ' value for the decadal investigation shows a positive trend in the NEMonsoon and negative trend for SW-Monsoon, Pre-Monsoon and Annual rainfall.

6) The ' $S$ ' value test conducted using 5 years mean values disclose that the rainfall in the monsoon months i.e. June to September is in the decreasing trend.

7) The ' $S$ ' value for the lustra analysis shows a significant decreasing trend of SW-Monsoon for the period 1995-99 and 2000-04.

From the above listed results, it is concluded that the trend of the rainfall is decreased in the study area which is one of the reasons for the drying of lakes in the study area.

\section{Acknowledgements}

The authors are thankful to the Director, Karnataka State Natural Disaster Monitoring Centre (KSNDMC), Bengaluru, India for providing the daily rainfall data for the research work. We pay sincere gratitude to all authors and experts for their efforts and contributions.

\section{References}

[1] Ganguly A, Chaudhuri RR, Sharma P. Analysis of Trend of the Precipitation Data : a Case Study of Kangra District , Himachal Pradesh. Int. J. Res. - GRANTHAALAYAH. 2015;3(9):87-95.

[2] Gavrilov MB. Id ő járás. 2016;120(2):183-98.

[3] Hamed KH, Ramachandra Rao A. A modified Mann-Kendall trend test for autocorrelated data. J. Hydrol. 1998;204(1-4):182-96.

[4] Jagadeesh P, Anupama C. Statistical and trend analyses of rainfall: A case study of Bharathapuzha river basin, Kerala, India. ISH J. Hydraul. Eng. 2014;20(2):119-32.

[5] Jain SK, Kumar V. Trend analysis of rainfall and temperature data for India. Curr. Sci. [Internet]. 2012;102(1):37-49. Available from: http://www.academia.edu/download/44619413/Jain_2012__Trend_analysis_of_rainfall_and_temperature_data_for_India.pdf

[6] Kendall MG (Maurice G. Rank correlation methods. 2nd ed. London: Griffin; 1955.

[7] Kendall MG (Maurice G. Rank correlation methods. 4th ed. London: Griffin; 1975.

[8] Kumar V, Jain SK, Singh Y. Analysis of long-term rainfall trends in India. Hydrol. Sci. J. [Internet]. 2010;55(4):484-96. Available from: http://www.tandfonline.com/doi/abs/10.1080/02626667.2010.481373

[9] Laz OU, Rahman A. Trends in Extreme Rainfall Events in Tasmania, Australia. 2014;8(12):8248.

[10] Mann HB. Nonparametric Tests Against Trend Published by: Econometric Society Stable URL: http://www.jstor.org/stable/1907187 REFERENCES Linked references are available on JSTOR for this article: You may need to log in to JSTOR to access the linked references. 2016;13(3):245-59. Available from: http://www.jstor.org/stable/ 
[11] Nikhil Raj PP, Azeez PA. Trend analysis of rainfall in Bharathapuzha River basin, Kerala, India. Int. J. Climatol. 2012;32(4):533-9.

[12] Rahman MA, Begum M. Application Of Non Parametric Test For Trend Detection Of Rainfall In The Largest Island Of Bangladesh. J. Earth Sci. 2013;2(2):40-4.

[13] Ramesh K V, P G. The shrinking Indian summer monsoon. CSIR Rep. RR C. [Internet]. 2007; Available from: http://www.cmmacs.ernet.in/cmmacs/Publications/resch_rep/rrcm0709.pdf

[14] Salmi T, Maatta A, Anttila P, Ruoho-Airola T, Amnell T. Detecting Trends of Annual Values of Atmospheric Pollutants by the Mann-Kendall Test and Sen's Solpe Estimates the Excel Template Application MAKESENS. Finnish Meteorol. Institute, Air Qual. Res. 2002.

[15] Sen KP. Estimates of the Regression Coefficient Based on Kendall's Tau Author (s): Pranab Kumar Sen Source: Journal of the American Statistical Association, Vol. 63, No. 324 (Dec, 1968), pp. Published by: Taylor \& Francis, Ltd. on behalf of the A. 2018;63(324):1379-89.

[16] Singh P, Kumar V, Thomas T, Arora M. Basin-wide assessment of temperature trends in northwest and central India. Hydrol. Sci. J. 2008;53(2):421-33.

[17] Sushant S, Balasubramani K, Kumaraswamy K. Environmental Management of River Basin Ecosystems. 2015;21-42. Available from: http://link.springer.com/10.1007/978-3-319-13425-3

*Corresponding author.

E-mail address: suri.civ@ bmsce.ac.in/ kppradeepraja@yahoo.co.in/pradeepkp.cv13@bmsce.ac.in 